\title{
Silent information regulator 1 ameliorates oxidative stress injury via PGC-1a/PPARY-Nrf2 pathway after ischemic stroke in rat.
}

\section{Research}

Keywords:

Posted Date: December 10th, 2020

DOI: https://doi.org/10.21203/rs.2.24617/v2

License: (c) (1) This work is licensed under a Creative Commons Attribution 4.0 International License.

Read Full License

Version of Record: A version of this preprint was published at Brain Research Bulletin on November 1st, 2021. See the published version at https://doi.org/10.1016/j.brainresbull.2021.11.001. 


\section{Abstract}

The authors have requested that this preprint be withdrawn due to author disagreement.

\section{Full Text}

The authors have withdrawn this preprint from Research Square. 